УДК 355.02:061.1€С(477+4-6СС)

DOI: 10.33099/2707-1383-2020-38-4-295-303

Левчик В.В., полковник, слухач Інституту державного військового управління, Начіональний університет оборони Украӥни імені Івана Черняховського (Київ, Україна) ORCID: https://orcid.org/0000-0002-4537-7384

Клименко В.С., кандидат політичних наук, доцент, дочент кафедри стратегіі національної безпеки та оборони, Національний університет оборони Украйни імені Івана Черняховського (Київ, Україна) ORCID: https://orcid.org/0000-0002-3276-6866 Козинещь I.П., кандидат історичних наук, старший науковий співробітник, полковник, професор кафедри стратегї національної безпеки та оборони, Національний університет оборони України імені Івана Черняховського (Київ, Україна) ORCID: https://orcid.org/0000-0001-9214-3372

\title{
ВРЕГУЛЮВАННЯ КРИЗ В РАМКАХ СПІЛЬНОЇ ПОЛІТИКИ БЕЗПЕКИ І ОБОРОНИ ЄС: ІСТОРИЧНИЙ АСПЕКТ ТА АКТУАЛЬНІСТЬ ДЛЯ УКРАЇНИ
}

В статті розглянуто проведення Свропейським Союзом операцій та місій, як ефективного механізму з врегулювання криз в рамках Спільної політики безпеки і оборони СС та перспективи залучення до них визначених сил та засобів Збройних Сил України.

Починаючи з 1999 року, в рамках Спільної політики безпеки та оборони, СС реалізовує місії та операції на суші та в морі, мета яких - створення безпекового середовища. В статті досліджуються правові підстави і практичні можливості СС здійснювати миротворчу діяльність у всіх ї̈ формах в рамках Статуту ООН.

Для України, у розрізі ї̈ європейської та євроатлантичної зовнішньої політики, дана проблематика є актуальною і важливою.

Ключові слова: Європейський Союз, Спільна політика безпеки та оборони, місії, операчії, врегулювання криз, миротворча діяльність.

Постановка проблеми. Одним із найважливіших завдань, які Свропейський Союз ставить перед собою як перед міжнародним безпековим актором, є врегулю- вання конфліктів. Проте ще ніколи Європа не опинялася в ситуації, коли агресія проти однієї з європейських країн почалася через iii намагання інтегруватися до ЄС. Конфлікт 
в Україні $є$ безпрецедентним випадком в історії європейської інтеграції, розвиток якого та дії $€ \mathrm{C} з$ його врегулювання $\epsilon$ безумовно найбільшим викликом для майбутнього Євросоюзу.

Аналіз досліджень та невирішені аспекти проблеми. Питання ролі СС в процесах конфліктного врегулювання є одним 3 науково-практичних напрямків, що активно досліджуються сьогодні в західних політичних школах таки х дослідників, як C. Волф, Р. Вітман (Whitman R.G., Wolff S. 2010), Ф. Кемерон (Cameron F. 2006), H. Точчі (Tocci N. 2015).

В українській політичній думці проблематика діяльності $\mathrm{CC}$ як посередника в процесах урегулювання конфліктів досі не здобула належного висвітлення. Існують окремі роботи, в яких аналізується позиція СС щодо неврегульованих конфліктів Г. Шелест (Шелест, Г. 2014), а також роль європейського чинника в контексті врегулювання конфліктів - I. Максименка (Максименко, I.В. 2016), С. Білоцького (Білоцький, С.Д. 2009), О. Брусиловської (Брусиловська, О.I. \& Русова, О.С. 2014) та інших.

Водночас, виникнення збройного конфлікту на Сході України, одна 3 причин якого криється в євроінтеграційній політиці держави, актуалізує завдання вивчення діяльності $\mathrm{CC}$ відносно конфліктів, в розв'язанні яких він брав або бере участь.

Отже, метою даної статі є дослідження особливостей діяльності ЄС з урегулювання конфліктів з акцентом на визначення елементів попереднього історичного досвіду, що мають бути враховані українською стороною в контексті врегулювання проблеми Криму та конфлікту на Сході України.

Виклад основного матеріалу. Проголосивши відповідальність за безпеку та мир в Європі основним пріоритетом, керівництво ЄС докладає значних зусиль щодо зміцнення міжнародного авторитету ЄС як організації, здатної ефективно реагувати на кризові ситуації в різних регіонах світу в рамках реалізації Спільної політики безпеки і оборони ЄС (далі СПБО).

Починаючи з 2003 року, з моменту запровадження Європейської політики безпеки та оборони як окремого напряму своєї діяльності, ЄС провів та продовжує проводити 36 місій та операцій у сфері СПБО (табл. 1), (Military and civilian missions and operations. 2019). При цьому лише дві операції ЄС здійснювались із використанням ресурсів НАТО та застосуванням механізму «Берлін-плюс», а саме: військова операція СС «Конкордія» та операція СС в Боснії і Герцеговині «ALTHEA» (Свропейський Союз. 2008, с. 195).

Станом на сьогодні близько 5000 військовослужбовців та цивільних беруть участь у 17 місіях та операціях $\mathrm{CC}$ в рамках СПБО, більшість яких проводиться за межами Європейського континенту (табл. 2), (Military and civilian missions and operations. 2019).

В рамках зусиль ООН щодо стабілізації ситуації в Лівії та посилення міжнародних санкцій, якими впроваджено ембарго на постачання зброї в цю країну, Радою СС було прийнято рішення щодо зміни 31 квітня 2020 року формату проведення військово-морської операції СС в Середземному морі «Софія» та перетворення іiї на військово-морську операцію $Є С$ в Середземному морі «Іріні». В рамках нової операції також планується: моніторинг та збір інформації щодо незаконного постачання з Лівії нафти та продуктів іï переробки; розбудова спроможностей та підготовка підрозділів лівійської берегової охорони та ВМС; участь у міжнародних зусиллях щодо припинення незаконної міграції (Military and civilian missions and operations. 2019). 
ПОТОЧНА КІЛЬКІСТЬ ОПЕРАЦІЙ ТА МІСІЙ ЄС

Типи операцій та місій $Є С$

з урегулювання кризових ситуацій

Кількість

\begin{tabular}{|c|c|c|c|}
\hline \multirow{2}{*}{ з урегулювання кризових ситуацій } & тривають & завершені & всього \\
\cline { 2 - 4 } & $\mathbf{1 7}$ & $\mathbf{1 9}$ & $\mathbf{3 6}$ \\
\hline військові & 6 & 7 & 13 \\
\hline цивільні & 11 & 12 & 23 \\
\hline
\end{tabular}

ПОТОЧНІ ОПЕРАЦІЇ ТА МІСІЇ СС В РАМКАХ СПБО

Таблиия 2

\begin{tabular}{|c|c|c|c|}
\hline $\begin{array}{l}\text { № } \\
\text { 3/II }\end{array}$ & $\begin{array}{c}\text { Операції (місії) з урегулювання } \\
\text { криз під проводом ЄС }\end{array}$ & $\begin{array}{c}\text { Місце } \\
\text { проведення }\end{array}$ & $\begin{array}{c}\text { Термін } \\
\text { початку }\end{array}$ \\
\hline \multicolumn{4}{|c|}{ Військові операції (місії) } \\
\hline 1 & Військова операція СС «Алтея» в БІГ (EUFOR Althea) & Боснія і Герцеговина & 302.12 .2004 \\
\hline 2 & $\begin{array}{l}\text { Військово-морська операція } \text { С із боротьби з піратством } \\
\text { «Аталанта» (EU NAVFOR Atalanta) }\end{array}$ & Індійський океан & 3 12.11.2008 \\
\hline 3 & Тренувальна місія ЄС в Сомалі (EUTM Somalia) & Сомалі & 310.04 .2010 \\
\hline 4 & Тренувальна місія ЄC в Малі (EUTM Mali) & Малі & 318.02 .2013 \\
\hline 5 & Тренувальна місія ЄС в ЦАР (EUTM RCA) & ЦАР & 317.06 .2016 \\
\hline 6 & $\begin{array}{l}\text { Військово-морська операція СС в Середземному морі } \\
\text { «Іріні» (EU NAVFOR MED IRINI) }\end{array}$ & Середземне море & $\begin{array}{c}\text { з квітня } \\
2020 \\
\end{array}$ \\
\hline \multicolumn{4}{|c|}{ Ц Цивільні операції (місії) } \\
\hline 7 & $\begin{array}{l}\text { Місія ЄС з надання допомоги на прикордонному } \\
\text { пропускному пункті Рафах (EUBAM Rafah) }\end{array}$ & Палестинська автономія & з 30.11.2005 \\
\hline 8 & $\begin{array}{l}\text { Поліцейська місія ЄС в Палестинській автономії } \\
\text { (EUPOL COPPS) }\end{array}$ & Палестинська автономія & 301.01 .2006 \\
\hline 9 & Правоохоронна місія ЄС в Косові (EULEX Kosovo) & Косово & 316.02 .2008 \\
\hline 10 & Спостережна місія ЄС в Грузії (EUMM Georgia) & Грузія & 301.10 .2008 \\
\hline 11 & $\begin{array}{l}\text { Операція СС з нарощування морського потенціалу Сомалі } \\
\text { (EUCAP Somalia) }\end{array}$ & Сомалі & 301.07 .2012 \\
\hline 12 & $\begin{array}{l}\text { Операція СС з нарощування потенціалу Нігеру, Сахель } \\
\text { (EUCAP SAHEL Niger) }\end{array}$ & Нігер & з 16.07.2012 \\
\hline 13 & $\begin{array}{l}\text { Мiciя ЄС з надання допомоги в питаннях кордону в Лівії } \\
\text { (EUBAM Libya) }\end{array}$ & Лівія & 3 22.05.2013 \\
\hline 14 & $\begin{array}{l}\text { Операція СС з нарощування потенціалу Малі, Сахель } \\
\text { (EUCAP SAHEL Mali) }\end{array}$ & Малі & з 15.04.2014 \\
\hline 15 & Дорадча місія ЄС в Україні (EUAM Ukraine) & Україна & 301.12 .2014 \\
\hline 16 & Дорадча місія ЄС в Іраку (EUAM Iraq) & Ірак & 317.10 .2017 \\
\hline 17 & Дорадча місія ЄС в ЦАР (EUAM RCA) & ЦАР & 301.06 .2020 \\
\hline \multicolumn{4}{|c|}{ Місії СС які проводяться поза межами СПБО } \\
\hline 18 & $\begin{array}{l}\text { Місія Європейської комісії з надання допомоги } \\
\text { в питаннях кордону в Україні та Молдові } \\
\text { (EUBAM Moldova and Ukraine) }\end{array}$ & Молдова, Україна & 301.12 .2005 \\
\hline
\end{tabular}


Також в рамках міжнародних дій зі стабілізації обстановки в Центральноафриканській республіці Рада ЄС прийняла рішення про започаткування Дорадчої місії ЄС в ЦАР, з досягненням повних оперативних спроможностей у червні 2020 року. Нова цивільна місія працює у взаємодії Тренувальною місією СС в ЦАР, яка була заснована у 2016 році.

Таким чином, рішення про започаткування нової операції та місії в рамках СПБО в районі Середземного моря та центральній Африці підтверджує прагнення СС відігравати більш впливову та різнопланову роль у міжнародній діяльності з врегулювання кризових ситуацій.

Правові аспекти фінансування цивільних та військових операцій $\mathrm{CC}$ в рамках СПБО регулюються положеннями статті 28 чинного Договору про Свропейський Союз (Угоди Свропейського Союзу).

Відповідно до цих положень, цивільні операції фінансуються 3 колективного бюджету СС за статтею «Витрати на реалізацію Спільної зовнішньої та безпекової політики $Є С »$ (Сайт Секретаріату Ради EC).

Військові операції $Є С$, відповідно до чинного законодавства, не можуть фінансуватися з колективного бюджету СС. При проведенні таких операцій діє принцип «кожен сплачує за себе», що суттєво впливає на прийняття країнами рішення про участь в тій чи іншій операції під егідою ЄС. За рахунок спільного фонду, що формується для проведення кожної окремої військової операції $€ \mathrm{C}$, сплачується лише незначна частина коштів - зазвичай, ці витрати не перевищують 10-15\% загальної «вартості» операції.

Внески країн СС на проведення військових операцій визначаються відповідно до рівнів валових національних продуктів. У разі участі третіх країн чи організацій відповідна частина витрат на проведення операції оплачується за рахунок їх внесків.

Під час підготовчої фази операції до призначення командувача кошти зі спільного фонду надаються безпосередньо у розпорядження національних контингентів (Концепція логістичного забезпечення військових операцій СС. 2008).

Після призначення командувача операцією ЄС кошти розподіляються на забезпечення розгортання штабів та підрозділів, а також на додаткове обладнання та евакуацію осіб, що потребують медичної допомоги. За рішенням Ради ЄС можливе спільне фінансування заходів 3 транспортування військ та їх розміщення (до цього часу практично не було реалізовано).

Україна має значний досвід співпраці 3 ЄС у безпековій сфері (Угода між Європейським Союзом і Україною про визначення загальної схеми участі України в операціях Європейського Союзу із врегулювання криз. 2005). 3 введенням в дію Указу Президента України «Про рішення Ради національної безпеки і оборони України від 21 квітня 2011 року «Про участь Збройних Сил України у багатонаціональних військових формуваннях високої готовності» практично було завершено формування національної нормативно-правової бази, що регулює залучення сил та засобів Збройних Сил України до операцій та місій СС в рамках СПБО, включаючи участь в Бойових тактичних групах ЄС (далі - БТГ ЄС).

Враховуючи спектр проведення операцій та місій ЄС (табл.2), наразі опрацьовується питання щодо залучення національного персоналу (штабних офіцерів) ЗСУ до участі у військовій операції СC “ALTHEA" в Боснії і Герцеговині (В СС схвалили участь українських військових в миротворчій місії в Боснії. 2020).

Беручи до уваги позитивний досвід послідовного залучення активів ВМС ЗСУ 
до участі в операції НАТО «Океанський щит» та ЄС «Аталанта» у 2013-2014 роках, перспективним виглядає можливість ïx залучення до операцій, які проводяться в Середземному морі - НАТО «Морський охоронець» та $Є \mathrm{C}$ «Іріні»:

- два патрульних катери класу "Island" та контактний пункт Військово-Морських Сил Збройних Сил України, починаючи з 2021 року;

— багатоцільовий фрегат «Гетьман Caгайдачний» 3 корабельним вертолітним комплексом та бойовою тактичною командою, починаючи з 2023 року.

Триває робота щодо перспективного залучення визначених сил і засобів ЗС України (рота морської піхоти, важкий транспортний літак Іл-76МД та групи штабних офіцерів) до БТГ СС “HELBROC” у першій половині 2023 року, з можливістю їх подальшого залучення до операції $\mathrm{CC}$ з врегулювання криз.

Крім цього, з польською та литовською сторонами в робочому порядку опрацьовується питання щодо можливості та варіантів залучення національних складових спільної литовсько-польсько-української бригади (ЛИТПОЛУКРБРИГ) до чергування в якості БТГ ЄС.

Це стало можливим у після офіційного визнання у 2016 році набуття командуванням бригадою повних оперативних спроможностей і готовності ЛИТПОЛУКРБРИГ до виконання завдань за призначенням та підписанням 5 жовтня 2017 року Угоди між Урядом Литовської Республіки, Урядом Республіки Польща та Кабінетом Міністрів України про внесення змін до Угоди між Урядом Литовської Республіки, Урядом Республіки Польща та Кабінетом Міністрів України стосовно створення спільної військової частини, положення якої дозволили значно розширити спектр участі ЛИТПОЛУКРБРИГ в Міжнародних операціях з підтримання миру і безпеки.

Наведені приклади лише підтверджують прагнення нашої держави реалізовувати свій миротворчий потенціал спільно 3 іншими державами для зміцнення міжнародної безпеки. Україна, як партнер СС, завжди була важливим учасником миротворчих операцій $\mathrm{CC} \mathrm{-} \mathrm{на} \mathrm{Балканах} \mathrm{та} \mathrm{у} \mathrm{боротьбі}$ з піратами біля узбережжя Африканського Рогу.

Впродовж багатьох років Україна робила свій внесок у міжнародні безпекові зусилля і ресурси для миротворчих операцій, але сьогодні сама потребує підтримки партнерів. Тому ми розраховуємо на взаємність і солідарність Європейського Союзу. Ще у 2015 році РНБО України прийняла рішення звернутися до Ради Безпеки ООН та Ради СС із проханням про розгортання на території України міжнародної операції 3 підтримання миру і безпеки. 18 березня 2015 року Представництво України при СС передало керівництву Євросоюзу відповідне звернення, схвалене Верховною Радою (Єлісєєв, К. 2015). Але, на жаль, на даний час вирішення цього питання не $є$ пріоритетом Євросоюзу.

Висновки та перспективи подальшого дослідження. Безумовно, що основною ідеєю ЄС є безпека європейських країн та громадян. Свросоюз з кінця 90-х років розвиває інституційну та інструментальну базу з кризового менеджменту, розглядаючи неврегульовані конфлікти як основні джерела загрози та нестабільності. Однак Свропейський Союз досі не перетворився на ефективний інструмент в цій сфері. Методи конструктивістського підходу до розв'язання та протидії конфліктам, які застосовуються в $\mathrm{CC}$, розраховані на тривалий період для реалізації європейських ідей та норм, що й визначає обмеженість 
можливостей та умовну ефективність стратегії ЄC.

Роль $\mathrm{CC} \mathrm{в} \mathrm{європейській} \mathrm{системі} \mathrm{без-}$ пеки в більшій мірі як «м'якої сили» обумовлює також i той факт, що конфлікт в Україні, всупереч стратегічним інтересам та цілям $\mathrm{CC}$, триває, так би мовити, поза контролем Європейського Союзу. Та використання потенціалу СС є надзвичайно важливим для України. Незважаючи на наші пропозиції і намагання, очевидно, що не варто очікувати на швидкі успіхи посередницької ролі чи миротворчих ініціатив ЄС. Але необхідно розвивати взаємодію для мінімізації загроз та корегування під- ходів з боку СС до ситуації в Україні, а також сприяти діалогу $\mathrm{CC}$-Росія щодо української ситуації та гарантій безпеки. Політична та економічна підтримка Європейського Союзу безумовно сприятиме створенню соціально-економічної платформи для протистояння агресії та стабілізації ситуації в Україні.

Розуміння основних принципів та механізмів дії $\mathrm{CC}$ дозволить передбачити можливі ризики та проблеми, розробити адекватну українським реаліям стратегію залучення СС до кризи в Україні, що у сукупності сприятиме безпеці та миру в нашій державі та у Свропі в цілому.

\section{СПИСОК ВИКОРИСТАНИХ ДЖЕРЕЛ}

В ЄС схвалили участь українських військових в миротворчій місії в Боснії. 2020. Європейська правда, 17 липня. URL: https://www.eurointegration.com.ua/rus/news /2020/07/17/7112227/ [дата зверн.: 16.10.2020]

Білоцький, С. Д. 2009. Міжнародно-правове регулювання миротворчої діяльності ЄС. Українсько-грецький міжнародний науковий юридичний журнал «Порівняльно-правові дослідження». 2. 56-61.

Брусиловська, О. I.\& Русова, О.С. 2014. Роль країн Веймарського трикутника у процесі прийняття та реалізації Лісабонської угоди. Наукові праці. Серія: Політологія. Миколаїв: ЧДУ імені Петра Могили. Вип. 216. Т. 288. 14-17.

Європейський Союз / колектив авторів; за заг. ред. О.І.Пошедіна. - 2-ге вид, доп. та вип. 2008. Київ: НАОУ. 397.

Єлісєєв, К. 2015. Операція СС — оптимальний варіант врегулювання на Донбасі. Європейська правда 21 березня. URL: https://ukraine-eu.mfa.gov.ua/news/34712-jelisejevoperacija-jesoptimalynij-variant-vregulyuvannya-na-donbasi [дата зверн.: 16.10.2020]

Концепція логістичного забезпечення військових операцій під проводом СC (EU Concept for Logistic Support for EU-led Military Operations) (документ 10963/08 COSDP 555 від 19.06.08). URL: http://register.consilium.europa.eu/pdf/en/04/st16/st16200.en04.pdf. [дата зверн.: 16.10.2020]

Максименко, I.В. 2016. Європейський Союз та врегулювання конфліктів: досвід та уроки для України. Міжнародні відносини. Серія «Політичні науки». 11. 18-25.

Сайт Секретаріату Ради CC. URL: http://www.consilium.europa.eu. [дата зверн.: 16.10.2020]

Угода між Європейським Союзом і Україною про визначення загальної схеми участі України в операціях Свропейського Союзу із врегулювання криз: ратифіковано Законом від 06.03.2008 р. № 137-VI. Відомості Верховної Ради України. 2015. № 23. ст. 212. 
Угоди Свропейського Союзу. URL: http://www.lisbon-treaty.org/wcm/the-lisbon-treaty.html. [дата зверн.: 16.02.2021]

Шелест, Г. 2014. Боснія: 20 років потому. Знову неспокійно. № 514 лютого. URL: https://zn.ua/ukr/international/bosniya-20-rokiv-potomu-znovu-nespokiyno-_html [дата зверн.: 16.10.2020]

Cameron F., Balfour R. The European Neighbourhood Policy as a conflict prevention tool / F. Cameron, R. Balfour // EPC Issue Paper. - 2006. — June, No.47

Military and civilian missions and operations. URL:https://eeas.europa.eu/ headquarters/ headquarters-homepage/430/military-and-civilian-missions-and-operations_en. [дата зверн.: 16.10.2020]

Tocci N. The EU in Conflict Resolution / N. Tocci // Conflict Resolution: Theories and Practice / Ed. by Stefan Wolff and Christalla Yakinthou. — London and New York: Routledge, 2011. _ Mode of access: www.ethnopolitics.org/isa/Tocci.pdf (5 October 2015).

Whitman R.G., Wolff S. The EU as a conflict manager? The case of Georgia and its implications / R.G. Whitman, S. Wolff // International Affairs. — 2010. — Vol. 86, № 1. — P. 1-21.

\section{REFERENCES}

V YES skhvalyly uchast ukrayinskykh viyskovykh v myrotvorchiy misiyi v Bosniyi. 2020. [The EU has approved the participation of the Ukrainian military in a peacekeeping mission in Bosnia]. URL: https://www.eurointegration.com.ua/rus/news/2020/07/17/7112227/[Accessend: 16.10.2020]. [in Ukrainian]

Bilockij, S.D. 2009. Mijnarodno-pravove regyluvannya mirotvorchoi diyalnosti ES [International legal regulation of EU peacekeeping activities]. Ukrainsko-greckij mijnarodnij naukovij uridichnij jyrnal "Porivnyalno-pravovi doslidgennya". 2. 56-61. [in Ukrainian].

Brysilovska, O. I.\& Rysova, O.S. 2014. Rol krayin Veymarskoho trykutnyka u protsesi pryynyattya ta realizatsiyi Lisabonskoyi uhody [The role of the Weimar Triangle countries in the adoption and implementation of the Lisbon Treaty]. Naukovi praci. Seriya: Politologia. Mikolaiv: CHDU imeni Petra Mogili. Vip. 216. T. 288. 14-17. [in Ukrainian].

Yevropeyski Soyuz. 2008. [European Union]. Za red. Pochedina O.I. Kyiv: NAOY. 397 [in Ukrainian].

Eliseev, K. 2015.Operaciya ES — optimalnij variant vregyluvannya na Donbasi [The EU operation is the best option for a settlement in Donbas] URL: https://ukraine-eu.mfa.gov.ua/ news/34712-jelisejev-operacija-jesoptimalynij-variant-vregulyuvannya-na-donbasi [Accessend: 16.10.2020]. [in Ukrainian].

Kontseptsiya lohistychnoho zabezpechennya viyskovykh operatsiy pid provodom YES. 2008. [EU Concept for Logistic Support for EU-led Military Operations]. Dokyment 10963/08 COSDP 555 vid 19.06.08. URL: http://register.consilium.europa.eu/pdf/en/04/st16/st16200. en04.pdf. [Accessend: 16.10.2020] [in English].

Maksimenko, I. V. 2016. Yevropeyskyy Soyuz ta vrehulyuvannya konfliktiv: dosvid ta uroky dlya Ukrayiny [The European Union and conflict resolution: experience and lessons for Ukraine]. Mijnarodni vidnosini. Seriya: polinichni nayki. 11. 18-25. [Accessend: 16.10.2020]. [in Ukrainian].

Sayt Sekretariatu Rady YES [Website of the Secretariat of the Council of the EU]. URL: http:// www.consilium.europa.eu. [Accessend: 16.10.2020] [in Ukrainian]. 
Uhoda mizh Yevropeyskym Soyuzom i Ukrayinoyu pro vyznachennya zahalnoyi skhemy uchasti Ukrayiny v operatsiyakh Yevropeyskoho Soyuzu iz vrehulyuvannya kryz [Agreement between the European Union and Ukraine on defining the general scheme of Ukraine's participation in the European Union crisis management operations]: ratifikovano Zakonom Ukrainy vid 06.03.2008 r. 137-VI. (2008). Vidomosti Verkhovnoi Rady Ukrainy, № 23, art. 212. [in Ukrainian].

Uhody Yevropeyskoho Soyuzu [Agreements of the European Union]. URL: http://www.lisbontreaty.org/wcm/the-lisbon-treaty.html. [Accessend: 16.10.2020] [in Ukrainian].

Shelest, G. 2014. Bosniya: 20 rokiv potomu. Znovu nespokiyno [Bosnia: 20 years later. Restless again]. URL: https://zn.ua/ukr/international/bosniya-20-rokiv-potomu-znovu-nespokiyno-.html [Accessend: 16.10.2020] [in Ukrainian].

Kemeron, F. \& Balfur, R. 2010. Yevropeyska polityka susidstva yak instrument zapobihannya konfliktam [The European Neighbourhood Policy as a conflict prevention tool]. Vypusk EPC. 47. [in English].

Viyskovi ta tsyvilni misiyi ta operatsiyi. 2019. [Military and civilian missions and operations]. URL: https://eeas.europa.eu/ headquarters/headquarters-homepage/430/military-and-civilianmissions-and-operations_en. [Accessend: 16.10.2020] [in English].

Tochchi, N. 2015. YES u vyrishenni konfliktiv [The EU in Conflict Resolution]. Vyrishennya konfliktiv: teoriyi ta praktyka. London i N'yu-York: Rutledzh. [Accessend: 16.10.2020] [in English].

Vitman, R.G. \& Volf, S. 2010. YES yak menedzher iz konfliktiv? Vypadok z Hruziyeyu ta yiyi naslidky [The EU as a conflict manager? The case of Georgia and its implications] . Mizhnarodni spravy.86. 1. 1-21. [Accessend: 16.10.2020] [in English]. 
Levchyk V.V., Colonel, Student of the State Milinary Governance Institute

The National Defense University of Ukraine named after Ivan Cherniakhovskyi (Kyiv, Ukraine) ORCID: https://orcid.org/0000-0002-4537-7384

Klymenko V.S., Candidate of Political Sciences, Docent, Docent of Academic department of strategy of national safety and defensive The National Defense University of Ukraine named after Ivan Cherniakhovskyi (Kyiv, Ukraine) ORCID: https://orcid.org/0000-0002-3276-6866

Kozinets I.P., Candidate of Historical Sciences, Senior Research Fellow, Colonel, Professor of Academic department of strategy of national safety and defensive The National Defense University of Ukraine named after Ivan Cherniakhovskyi (Kyiv, Ukraine) ORCID: https://orcid.org/0000-0001-9214-3372

\section{CRISIS MANAGEMENT IN THE FRAMEWORK OF THE EU COMMON SECURITY AND DEFENSE POLICY: HISTORICAL ASPECT AND RELEVANCE FOR UKRAINE}

In order to optimize the diplomatic and humanitarian efforts, the EU has conducted a number of operations and missions in the framework of Common Security and Defense Policy in recent decades. They are one of the main tools for addressing peace and security issues in the area of the organization's vital interests. The European External Action Service in Brussels coordinates all activities of the EU and Member States in this area.

The article specify the European Union's operations and missions as an effective mechanism for crisis management in the framework of the EU Common Security and Defense Policy, the procedures for their financing and the perspectives of involving to them designated forces and means of the Armed Forces of Ukraine.

Since 1999, under the Common Security and Defense Policy, the EU has been conducting land and sea missions and operations aimed at creating a secure environment, combating piracy and illegal trade, and cooperating with the judiciary.

Gradually moving through the stages of integration, the EU has set itself increasingly difficult tasks in the field of peace and security. At the same time, the military component in the EU still does not fully meet the specific requirements set for the crisis response operations. This encourage the EU to look for cooperation mechanisms with other organizations that have a strong militarypolitical nature, especially with NATO.

The article notes the existence of legal bases and practical opportunities in the EU to carry out peacekeeping activities in all its forms. At the same time, the European Union declares its respect for the norms of the UN Charter.

This issue is relevant and important for Ukraine in the context of its European and EuroAtlantic foreign policy.

Key words: European Union, Common Security and Defense Policy, missions, operations, crisis response, peacekeeping activities. 